\title{
Directly Cytoplasmic Delivery and Nuclear Targeting Delivery of HPMA-MT Conjugates in a Microtubules Dependent Fashion
}

\author{
Jiaju Zhong ${ }^{\mathrm{a}}$, Xi Zhu ${ }^{\mathrm{a}}$, Kui Luo ${ }^{\mathrm{b}}$, Lian $\mathrm{Li}^{\mathrm{a}}$, Manlin Tanga, Yanxi Liu ${ }^{\mathrm{a}}$, Zhou \\ Zhou $^{\mathrm{a}}$, and Yuan Huang ${ }^{\mathrm{a}, *}$ \\ ${ }^{a}$ Key Laboratory of Drug Targeting and Drug Delivery System (Ministery of Education), West China \\ School of Pharmacy, Sichuan University, NO. 17, Block 3, South Renmin Road, Chengdu 610041, P.R. \\ China \\ ${ }^{\mathrm{b}}$ Huaxi MR Research Center (HMRRC), Department of Radiology, West China Hospital, Sichuan \\ University, Chengdu 610041, China
}


1 Characterization of Copolymer Conjugates.

1.1 The $-\mathrm{NH}_{2}$ Content in HPMA Polymers

The content of $-\mathrm{NH}_{2}$ in HPMA polymers was determined by TNBSA assay. To $0.5 \mathrm{~mL}$ of HPMA conjugate solutions $(10 \mathrm{mg} / \mathrm{mL})$ in $0.1 \mathrm{M}$ sodium bicarbonate buffer $(\mathrm{pH} 8.5), 0.25 \mathrm{~mL}$ of $0.01 \%$ TNBSA was added. The mixtures were incubated at $37^{\circ} \mathrm{C}$ for $2 \mathrm{~h}$. To solubilize the polymer and avoid their precipitation, $0.25 \mathrm{~mL}$ of $10 \%$ sodium dodecyl sulfate and $0.125 \mathrm{~mL}$ of $1 \mathrm{M} \mathrm{HCl}$ were added to above mixtures. The absorbance of the reaction mixtures was measured at UV-vis $335 \mathrm{~nm}$ against a buffer blank. The standard curve was constructed using APMA. All assays were run in triplicates.

\subsection{The FITC Contents in HPMA Polymers}

The loading efficiency of FITC was determined by UV-vis. Briefly, FITC labeled HPMA polymers was dissolved in sodium tetraborate buffer $(\mathrm{pH} 9.0)$ in concentration of $0.5 \mathrm{mg} / \mathrm{mL}$. The absorbance of the reaction mixtures was measured at UV-vis $491 \mathrm{~nm}$ against a buffer blank. The standard curve was constructed using free FITC. All assays were run in triplicates.

\subsection{The Peptide Contents in HPMA Polymers}

The peptide conjugated HPMA polymers (GG, H1, NLS, MT and 
MT-m) was dissolved in $6 \mathrm{M} \mathrm{HCl}$, and hydrolyzed in $80^{\circ} \mathrm{C}$ for $24 \mathrm{~h}$. The peptides contents (GG, H1, MT, MT-m and NLS) were measured by amino acid analysis (Commonwealth Biotech, VA). Acetylene (MA-GG-C $\equiv \mathrm{CH}$ ) content was determined from the amount of GG sequences.

1.4 The Molecular Weight (MW) and Polydispersity Index (PDI) of Different Polymer Conjugates

The MW and PDI of HPMA polymers were estimated by size exclusion chromatography on a Superose 200 10/300 GL analytical column (Amersham Biosciences, NJ) calibrated with poly (HPMA) fractions. PBS was used as mobile phase and the detection was performed by refractive index detector (KNAUER, 2300). 


\section{Extraction Recovery}

HeLa cells were seeded at $1.5 \times 10^{6}$ cells in a 6-cm petri dish for 24 h. After that, the cells were washed with cold PBS three times, trypsinized and suspended at a concentration of $5 \times 10^{6}$ cells $/ \mathrm{mL}$ for 20 min at $4{ }^{\circ} \mathrm{C}$ in a $100 \mathrm{mM} \mathrm{NaCl}$ solution with $1 \mathrm{mM}$ EDTA, $1 \%$ Triton $\mathrm{X}-100$, and $10 \mathrm{mM}$ Tris buffer $(\mathrm{pH}$ 7.4). The suspension was then centrifuged (15 min, $800 \mathrm{~g}$ ), and the nuclei were separated from the supernatant (cytosol). Then, the nuclei were incubated with P-FITC-MT polymer at low $(0.05 \mathrm{mg} / \mathrm{mL})$, medium $(0.2 \mathrm{mg} / \mathrm{mL})$ and high $(0.6$ $\mathrm{mg} / \mathrm{mL}$ ) concentration level for $30 \mathrm{~min}$. Finally, methanol was added to extract the polymers at $4^{\circ} \mathrm{C}$ overnight. ${ }^{1,2}$ All examples were analyzed at each concentration using the equation:

Recovery $(\mathrm{RE})=($ Fluorescence intensity of test sample/Fluorescence intensity of references example) $\times 100$

Results were showed in table 1.

Table 1 Recovery test of P-FITC-MT $(n=5)$.

\begin{tabular}{ll}
\hline Concentration $(\mathrm{mg} / \mathrm{mL})$ & Recovery $(\%)$ \\
\hline 0.05 & $90.5 \pm 1.3$ \\
0.2 & $96.6 \pm 0.6$ \\
0.6 & $100.8 \pm 1.5$ \\
\hline
\end{tabular}




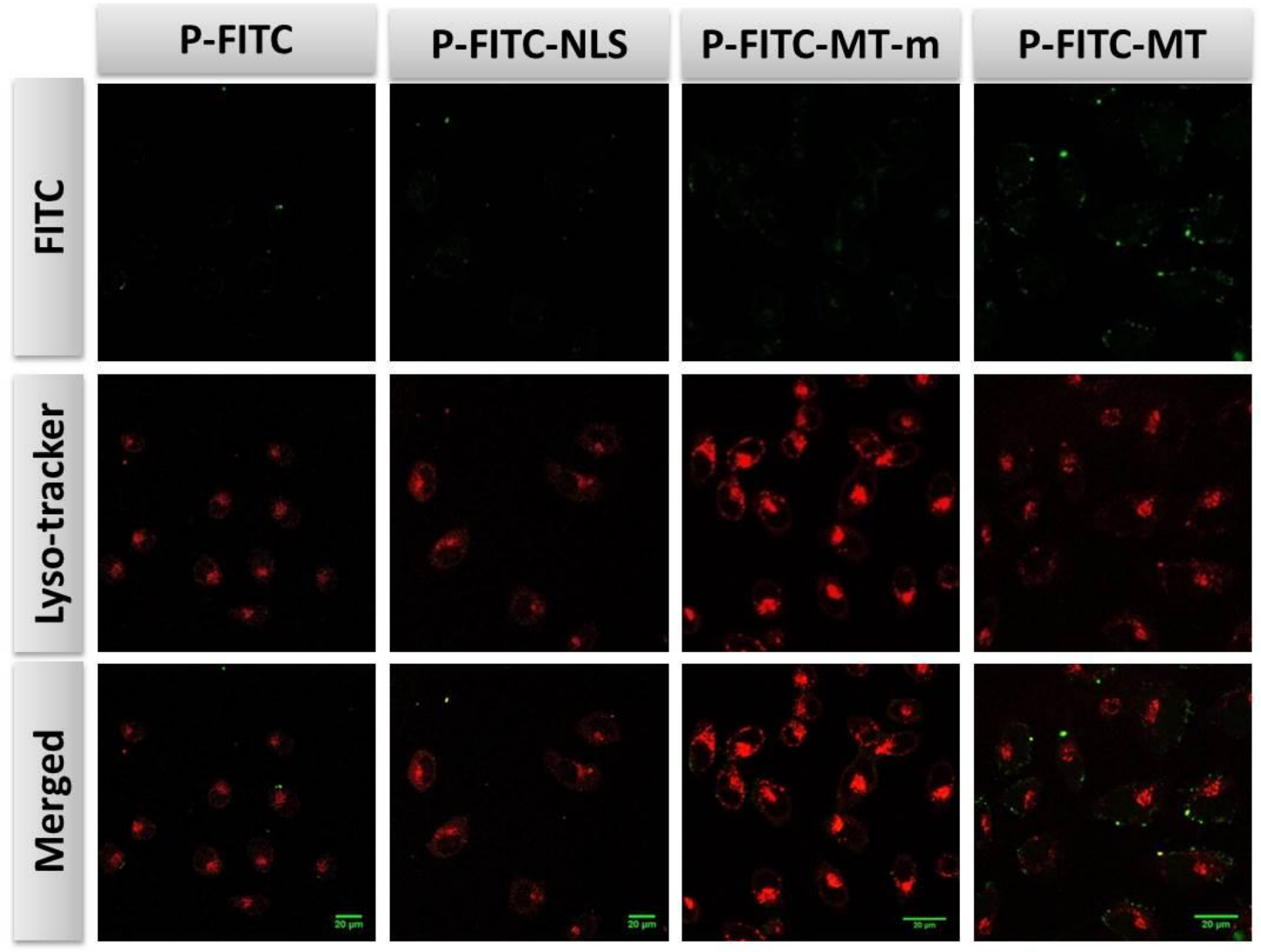

Figure 1 CLSM images of fluorescence intensity for Hela cells incubated for $1 \mathrm{~h}$ with FITC-labeled polymer conjugates, and the lysosome was stained with lyso-tracker (red). 


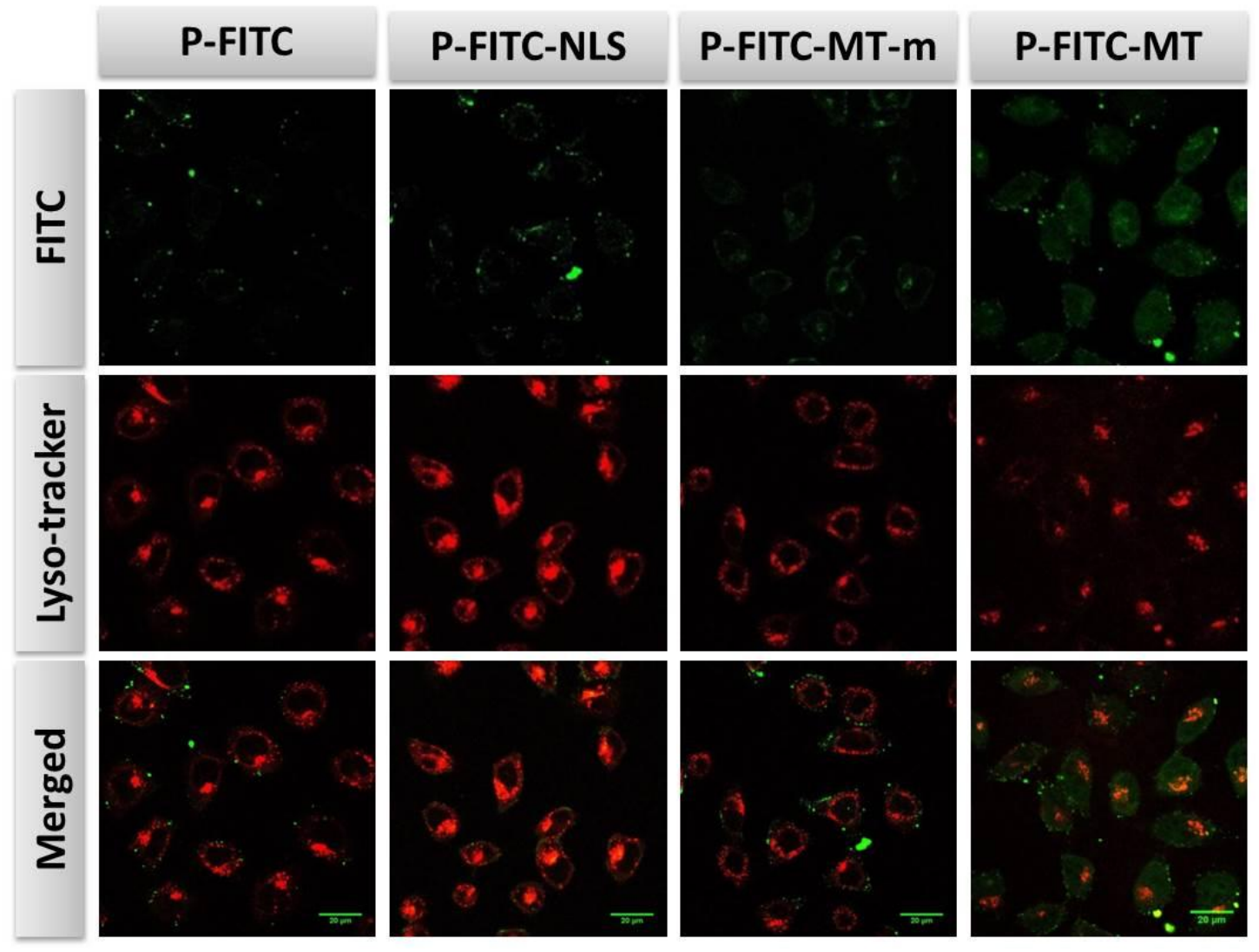

Figure 2 CLSM images of fluorescence intensity for Hela cells incubated for $4 \mathrm{~h}$ with FITC-labeled polymer conjugates, and the lysosome was stained with lyso-tracker (red). 


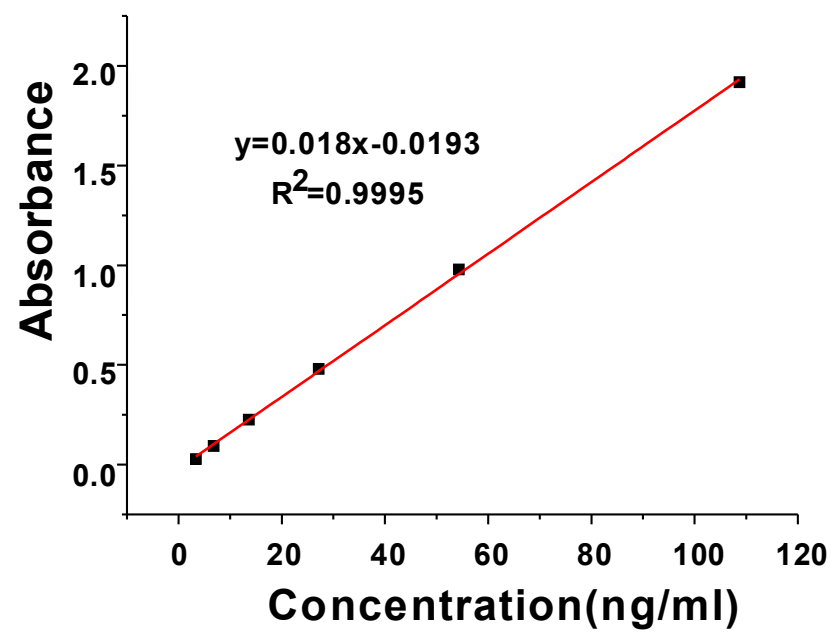

Figure 3 Standard curve of FITC. 


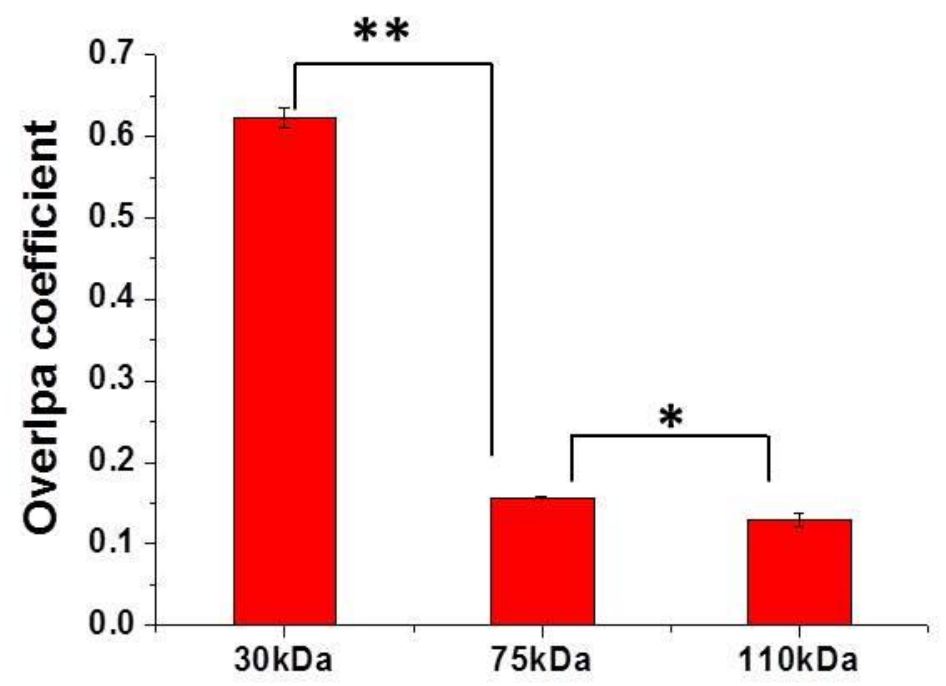

Figure 4 Quantitative colocalization analysis of P-FITC-MT $(\mathrm{Mw} \sim 30$, 75 and $110 \mathrm{kDa})$ with nucleus using Image $\mathrm{J}$ software, $* \mathrm{p}<0.05, * * \mathrm{p}<$ 0.01 . 

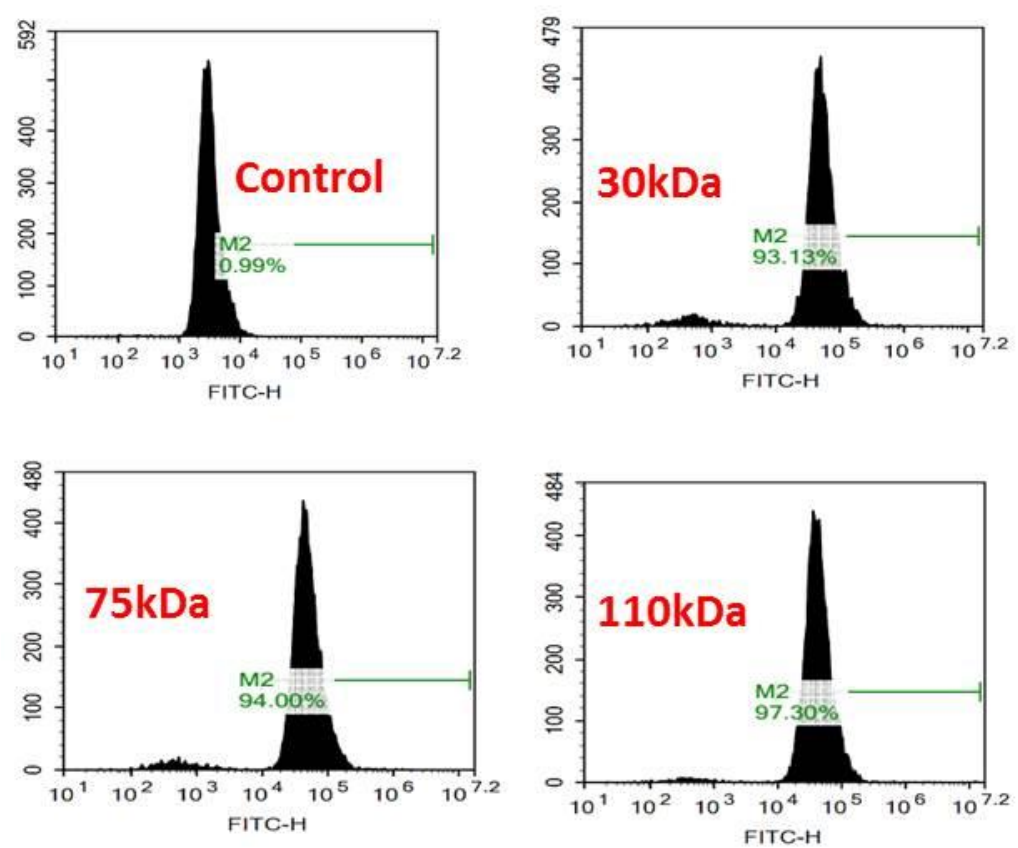

Figure 5 The cellular uptake of P-FITC-MT $(\mathrm{Mw} \sim 30,75$ and $110 \mathrm{kDa})$ determined by flow cytometry after $18 \mathrm{~h}$ incubation. 


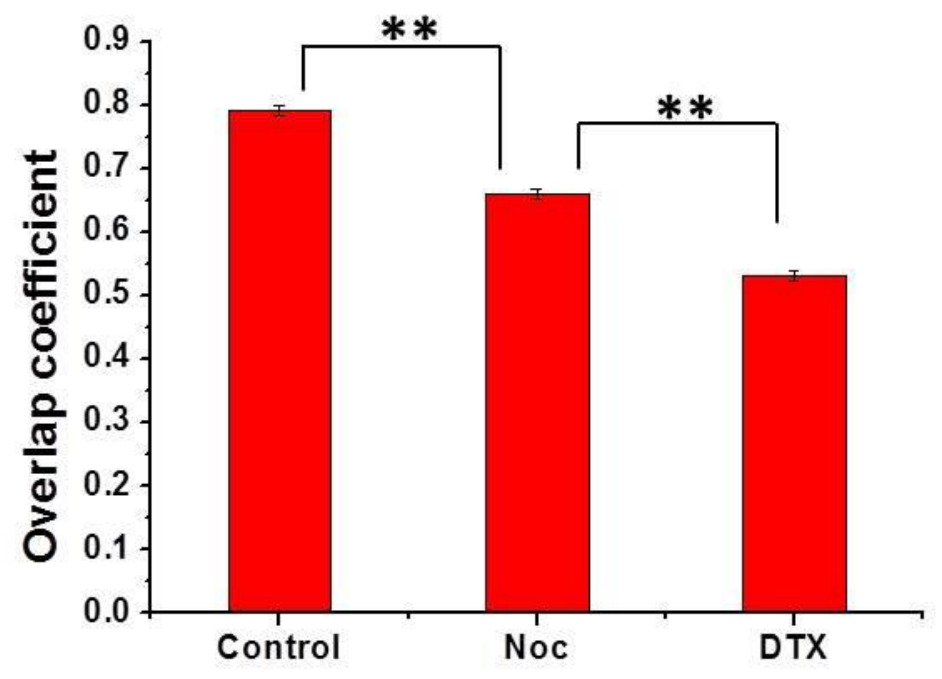

Figure 6 Quantitative colocalization analysis of P-FITC-MT (in the presence or absence of DTX and Noc) with nucleus using Image J software, ${ }^{* *} \mathrm{p}<0.01$. 


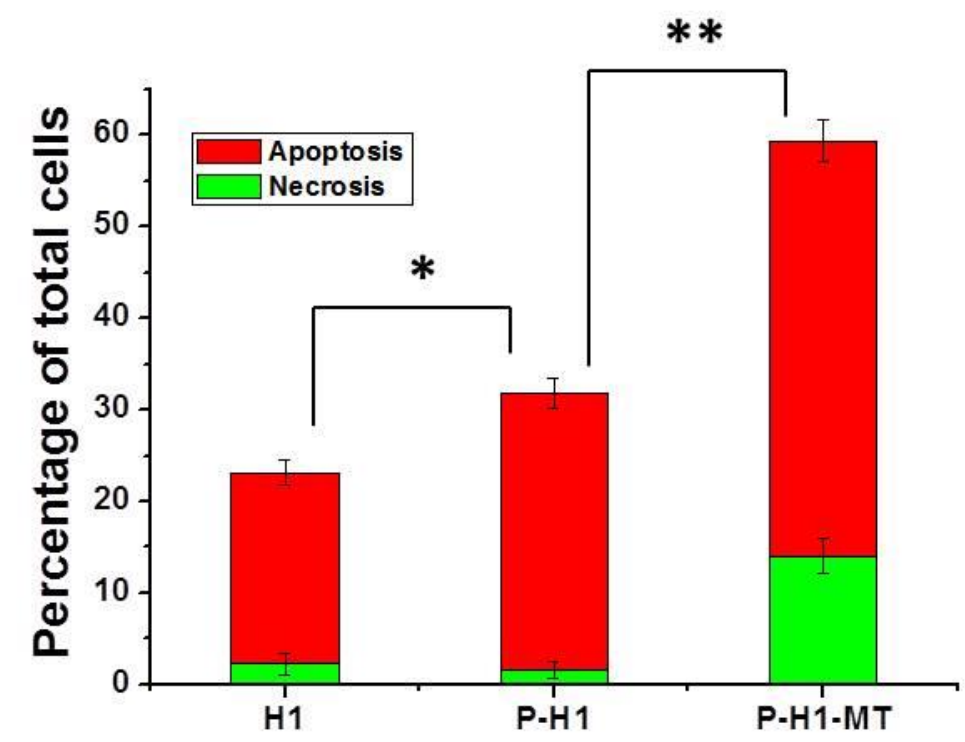

Figure 7 Cell apoptosis assay. Annexin-V/PI dual staining of HeLa cells was observed for detection of apoptotic/necrotic cells after $18 \mathrm{~h}$ culture with free $\mathrm{H} 1$ peptide, $\mathrm{P}-\mathrm{H} 1$ and P-H1-MT. Results are means $\pm \mathrm{SD}, \mathrm{n}=3$, $* \mathrm{p}<0.05, * * \mathrm{p}<0.01$ 


\section{Reference}

(1) Pan, L.; Liu, J.; He, Q.; Shi, J. MSN-mediated sequential vascular-to-cell nuclear-targeted drug delivery for efficient tumor regression. Adv. Mater. 2014, 26 (39), 6742-8.

(2) Liu, J. N.; Bu, W.; Pan, L. M.; Zhang, S.; Chen, F.; Zhou, L.; Zhao, K. L.; Peng, W.; Shi, J. Simultaneous nuclear imaging and intranuclear drug delivery by nuclear-targeted multifunctional upconversion nanoprobes. Biomaterials 2012, 33 (29), 7282-90. 